\title{
P̈̈̈̈KIRJOITUS
}

\section{TEKIJÄT TYÖNSÄ KEHITTÄJINÄ}

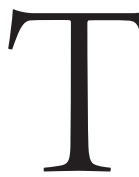

yöelämän laatu ja työhyvinvointi ovat olleet viime vuosina vilkastuvan keskustelun aihe. Erimielisyys ei koske vain sitä, onko työelämän laatu Suomessa hyvää vai huonoa tasoa ja voivatko työntekijät hyvin vai huonosti. Yhteistä ymmärrystä ei ole myöskään siitä, mihin suuntaan työelämä on viime vuosina kehittynyt ja mihin suuntaan se kehittyy tulevaisuudessa.

Työelämän laatua koskeva keskustelu kiertyy ehkä tiiviimmin kolmen asian ympärille. Eniten puhuttavat työelämän nopea ja hallitsematon muutos, kiire ja työpaineen aiheuttama pahoinvointi sekä työn mielekkyys. Työt ja tehtävät muuttuvat entistä nopeammassa tahdissa, ja muutosta on vaikea ennakoida. Se lisää epävarmuutta. Työ on entistä kiireisempää. Kun liiallisen kiireen vuoksi tehtävät joudutaan tekemään hätiköiden, laatu kärsii. Kun tekijällä ei ole mahdollisuutta tehdä tehtäviään niin hyvin kuin pystyisi, työtä on vaikea kokea mielekkääksi.

Varsinkin nuoremman sukupolven työntekijät panevat entistä suuremman painon työn mielekkyydelle. Nuoren sukupolven arvostuksissa työssä on voitava toteuttaa itseään. Edes kohtuullinen palkka ei kompensoi puuttuvaa mielekkyyttä. Nykyihminen ei halua tuhlata ainutkertaista elämäänsä. Tapa, jolla työelämää kehitetään, nousee niinikään keskeiseksi asiaksi: ihmiset haluavat itse osallistua kehittämiseen ja vaikuttaa siihen, mihin suuntaan ja miten työtä ja tehtäviä muutetaan.

Elinkeinoelämän Valtuuskunta EVA tuli hiljattain julkisuuteen omalla kannanotollaan Mainettaan parempi työ, jonka tarkoitus oli oikaista sitä yleistä käsitystä, jonka mukaan työelämä olisi jatkuvasti huonontunut. Syypää harhaluuloon on EVA:n mukaan yksipuoliset tutkimukset ja epäkohdilla mässäilevä media. EVA:n raportin mukaan ”työelämään liittyvä synkkä julkinen keskustelu luo ristiriitaisia ja harhaanjohtavia mielikuvia siitä, mitä työelämässä todellisuudessa tapahtuu. Totuus on, että mielikuvat työelämästä ovat huonontuneet - ei itse työelämä. Suomalaiset ovat työssään tyytyväisiä." Kuitenkin esimerkiksi työn mielekkyyden jatkuva väheneminen näkyy muun muassa työolobarometrin tuloksista.

Työelämän sukupolvimurrokseen ja eri ikäisten erilaisiin arvostuksiin huomiota kiinnittänyt Työja elinkeinoministeriö halusi nostaa keskusteluun uusia ajatuksia siitä, mitä hyvä työ ja työelämä ovat eri sukupolville. Hyvän työn manifestissa tartuttiin voimakkaasti erityisesti siihen tutkimustulokseen, että Suomi on työpaikkakiusaamisen kärkimaa. Työpaikkakiusaaminen on Suomessa kaksi kertaa yleisempää kuin Euroopassa keskimäärin. Usein kiusaaja on esimies. Kiusaamisen taustalla on muun 
muassa työnteon yhteisöllisen luonteen väheneminen ja se, että työntekijät joutuvat entistä kovemmin kilpailemaan keskenään. Hyvää työtä ja vakaata uraa kun ei tunnu riittävän läheskään kaikille: ”Lupaus pysyvästä työpaikasta on vaihtunut ketään säästämättömään kilpailuun ja metsästyksen kulttuuriin. -- Menestystä todistaessamme vakuutumme siitä, että tästä maailmassa on kysymys: atomisoituneiden yksilöiden sodasta toisiaan vastaan, jossa yhteisön toimintaa ja hyvinvointia ei ylläpidä kukaan.” Ekologisesti tietoinen sukupolvi ei tyydy vaikuttamaan vain siihen, miten ihmistä työelämässä kohdellaan, vaan myös siihen, mitä tuotetaan. Onko kaikki hyvää, mikä menee kaupaksi?

Tilastokeskuksen työolotutkimusten aikasarjat kolmen vuosikymmenen ajalta (vuosilta 19772008) eivät osoita yhdensuuntaista trendiä työelämän huononemisesta tai paranemisesta. On tapahtunut kumpaakin. Esimerkiksi käsitykset kehittymismahdollisuuksista työssä ovat työolotutkimuksen mukaan selvästi parantuneet kolmen vuosikymmenen aikana. Naisten kehittymismahdollisuudet ovat yleistyneet miehiä enemmän. Kehitysmahdollisuuksia hyvinä pitävien naisten osuus on noussut 23 prosentista 42 prosenttiin vuodesta 1977 vuoteen 2008. Hyvät kehittymismahdollisuudet ovat yhteydessä korkeaan koulutukseen ja ylempien toimihenkilöi- den työhön. Toisaalla naisten teollisessa työssä kehittymismahdollisuuksia pitää hyvinä edelleenkin vain joka viides. Voiko tilannetta sanoa hyväksi? Erot henkilöstöryhmien välillä ovat suuret muissakin asioissa. Esimerkiksi henkisen rasittavuuden naiset kokevat selvästi lisääntyneen kolmen vuosikymmenen aikana, voimakkaimmin kuntien töissä.

Anu Korhosen mukaan opetustyössä jatkuvalla syötöllä toistaan seuraavat muutokset ja kehittämistoimet uhkaavat jo hämärtää käsityksen koulujen perustehtävästä. Opettajat väsyvät jatkuviin muutoksiin. Niin kasvatettavan kuin työnteon mielekkyys tuntuu katoavan. Perustehtävälähtöisessä kehittämisotteessa muutoksiin reagoimisen rinnalla huomiota kiinnitetään vuosien saatossa pysyviin ja säilyttämisen arvoisina pidettäviin työn sisältöihin ja toteutustapoihin. On kyse tarkoituksenmukaisuutta ja työnteon mielekkyyttä korostavasta kehittämisestä.

Annarita Koli tähdentää, että työyhteisöt itse kykenevät systemaattisesti erittelemään ja tulkitsemaan työnsä ongelmatilanteita. Kehittämisen tapoja yhteisesti arvioimalla on mahdollista tukea työyhteisöjen toimijuutta oman työnsä kehittämisessä ja näin lisätä kehittämistyön vaikuttavuutta.

Heikki Silvennoinen 